\title{
Moderate biomanipulation for eutrophication control in reservoirs using fish captured in angling competitions
}

\author{
S.D. Amaral ${ }^{(1), \star}$, A. Franco ${ }^{(2)}$, M.T. Ferreira ${ }^{(1)}$
}

Received March 5, 2015

Revised April 22, 2015

Accepted April 26, 2015

\begin{abstract}
Key-words: angling, biomanipulation, eutrophication, fish management, groundbait

Angling competitions are a popular leisure activity in reservoirs of Southern Portugal. These competitions can gather more than 100 anglers aiming to catch the maximum fish weight. Groundbaiting and catch-andrelease angling are two common practices for anglers in competition. In this study, the loads of nutrients from commercial groundbait powders used in angling competitions in the Maranhão reservoir and the possible balance out of those nutrients through a moderate biomanipulation of the fish biomass caught in competitions were analysed. In order to achieve this aim, chemical analyses to groundbait powders most purchased by Portuguese anglers and to fish species most captured in competitions were made. Mass balances on inputs and outputs of nutrients considering some biomanipulation scenarios were evaluated. Results demonstrated that an effective management on angling competitions implementing a moderate biomanipulation of fish in reservoirs could promote the control of fish fauna and eutrophication, balancing out nutrients from angling.
\end{abstract}

\section{ABSTRACT}

\section{RÉSUMÉ}

Biomanipulation modérée pour le contrôle de l'eutrophisation dans les réservoirs à l'aide de poissons capturés dans les compétitions de pêche à la ligne

Mots-clés:
pêche à la ligne,
biomanipulation,
eutrophisation,
gestion
piscicole,
amorce

Les compétitions de pêche sont une activité de loisir populaire dans les réservoirs du sud du Portugal. Ces compétitions peuvent rassembler plus de 100 pêcheurs visant à attraper le poids maximum de poissons. L'amorçage et la pêche avec capture puis relâché sont deux pratiques communes pour les pêcheurs en compétition. Dans cette étude, les charges de nutriments à partir des poudres d'amorce commerciales utilisées dans ces compétitions de pêche dans le réservoir Maranhão et le solde possible de ces nutriments lors d'une biomanipulation modérée de la biomasse de poissons capturés dans les compétitions ont été analysés. Afin d'atteindre cet objectif, les analyses chimiques des poudres d'amorçage les plus achetées par les pêcheurs portugais destinées à pêcher les espèces les plus capturées dans les compétitions ont été faites. Les bilans massiques sur les entrées et sorties de nutriments suivant certains scénarios de biomanipulation ont été évalués. Les résultats ont démontré qu'une gestion efficace des compétitions de pêche mettant en œuvre une biomanipulation modérée de poisson dans les réservoirs pourrait favoriser le contrôle de la faune piscicole et l'eutrophisation en équilibrant les apports nutritifs de la pêche.

(1) Centro de Estudos Florestais (CEF), Instituto Superior de Agronomia - Universidade de Lisboa, Tapada da Ajuda, 1349 - 017 Lisboa, Portugal

(2) Divisão de Gestão dos Recursos Cinegéticos e Aquícolas, Instituto da Conservação da Natureza e das Florestas, Av da Republica 16 - 16B, 1050 - 191 Lisboa, Portugal

* Corresponding author: samaral@isa.ulisboa.pt 


\section{INTRODUCTION}

Iberian rivers are highly fragmented and dammed, with rosaries of reservoirs along the riverine longitudinal dimension (Santos et al., 2006; Alexandre et al., 2013). In Southern Portugal 70 large reservoirs are used mainly for agricultural irrigation and human water supply (location of Portuguese dams at http://www.snirh.pt), and most of these present eutrophication problems (River Basin Management Plans, http://www.inag.pt) related either to the absence of treatment of point sources of pollution (e.g. industrial discharges, municipal wastewater, mining), or to diffuse pollution sources from crop runoff, particularly of nitrogen and phosphorus (Smith et al., 1999; Carpenter and Lathrop, 2008), frequently associated with the excessive use of fertilizers and other agrochemicals.

Fish populations present in southern Portuguese reservoirs are mostly non-native species such as common carp (Cyprinus carpio Linnaeus, 1758), goldfish (Carassius auratus Linnaeus, 1758), largemouth bass (Micropterus salmoides Lacepède, 1802), pumpkinseed (Lepomis gibbosus Linnaeus, 1758), and recently bleak (Alburnus alburnus Linnaeus, 1758), along with rheophilic native species, typically barbel (Luciobarbus bocagei Steindachner, 1864; and Luciobarbus comizo Steindachner, 1864) and Iberian nase (Pseudochondrostoma polylepis Steindachner, 1864) (Banha et al., 2015). These native species are able to adapt to the environment of the reservoir displaying regular potamodromous cycles, spawning in tributaries and feeding in man-made lentic freshwater habitats (Ferreira and Godinho, 2002; Granado-Lorenço, 2002; Clavero and Hermoso, 2011; Clavero et al., 2013). In these reservoirs, heavy biomanipulations (see Hanson et al., 1998; Drenner and Hambright, 1999; Kasprzak et al., 2002; Mehner et al., 2002) destined to eradicate non-native species and to provide better conditions for native fish fauna may be difficult to justify and implement due to the special interest that species like common carp and largemouth bass have for anglers and for local economy. However, it would be positive to intervene in the ecosystem in order to maintain well-structured fish populations, and to improve water quality in an expeditious and inexpensive way.

Recreational angling is a popular leisure activity in Portugal with nearly 200000 anglers licensed for inland waters, as reported by the Institute for the Conservation of Nature and Forests (ICNF), the state agency managing inland fisheries. Most of the angling activity is organized by anglers' associations and takes place in large rivers and especially in reservoirs, gathering over 100 anglers per competition with the aim of catching the maximum fish weight. Groundbaiting is used in these competitions to attract fish to the fishing area. Normally commercial groundbait powders are used, composed mainly by flours (e.g., corn, peanut, and wheat), bread crumbs and crackers, aromatics and dyes, in different proportions depending on the target species. Worms, maggots, hemp seeds, corn and other grains are also added by anglers to the groundbait balls which are thrown into the reservoir. Nutrient loads resulting from groundbaiting may negatively affect water quality and trophic status (Wolos et al., 1992; Niesar et al., 2004; Arlinghaus and Niesar, 2005; Lewin et al., 2006; Amaral et al., 2013). Fish captured during the competition time (usually $4 \mathrm{~h}$ of angling) are kept in keepnets. At the end of the competition the fish caught are weighed and released back to the reservoir (voluntary catch-and-release angling is practised in general for conservation purposes) thus not allowing the control of fish biomass, especially of nuisance species (Arlinghaus, 2007), or the reduction of nutrients in the system through the removal of fish captured (Wolos et al., 1992; Niesar et al., 2004; Lewin et al., 2006).

Biomanipulation, even at a moderate level, has been indicated as a possible control tool mainly focused in the communities of benthic-planktonic fish like carp (Wiley and Wydoski, 1993; Weber and Brown, 2009), which are considered by several authors as drivers of eutrophication in reservoirs (Vanni, 2002; Chumchal et al., 2005; Fischer et al., 2013; Nieoczym and Kloskowski, 2013). Truly, the effective management of angling can be envisaged as a benefit to achieve a higher planning of fish fauna and water quality in reservoirs (Cowx and Gerdeaux, 2004; Mehner et al., 2004). Also, fish extraction may be used as a tool to balance the loads of nutrients from groundbaiting. Nevertheless, there is no such experience in Iberian reservoirs. 


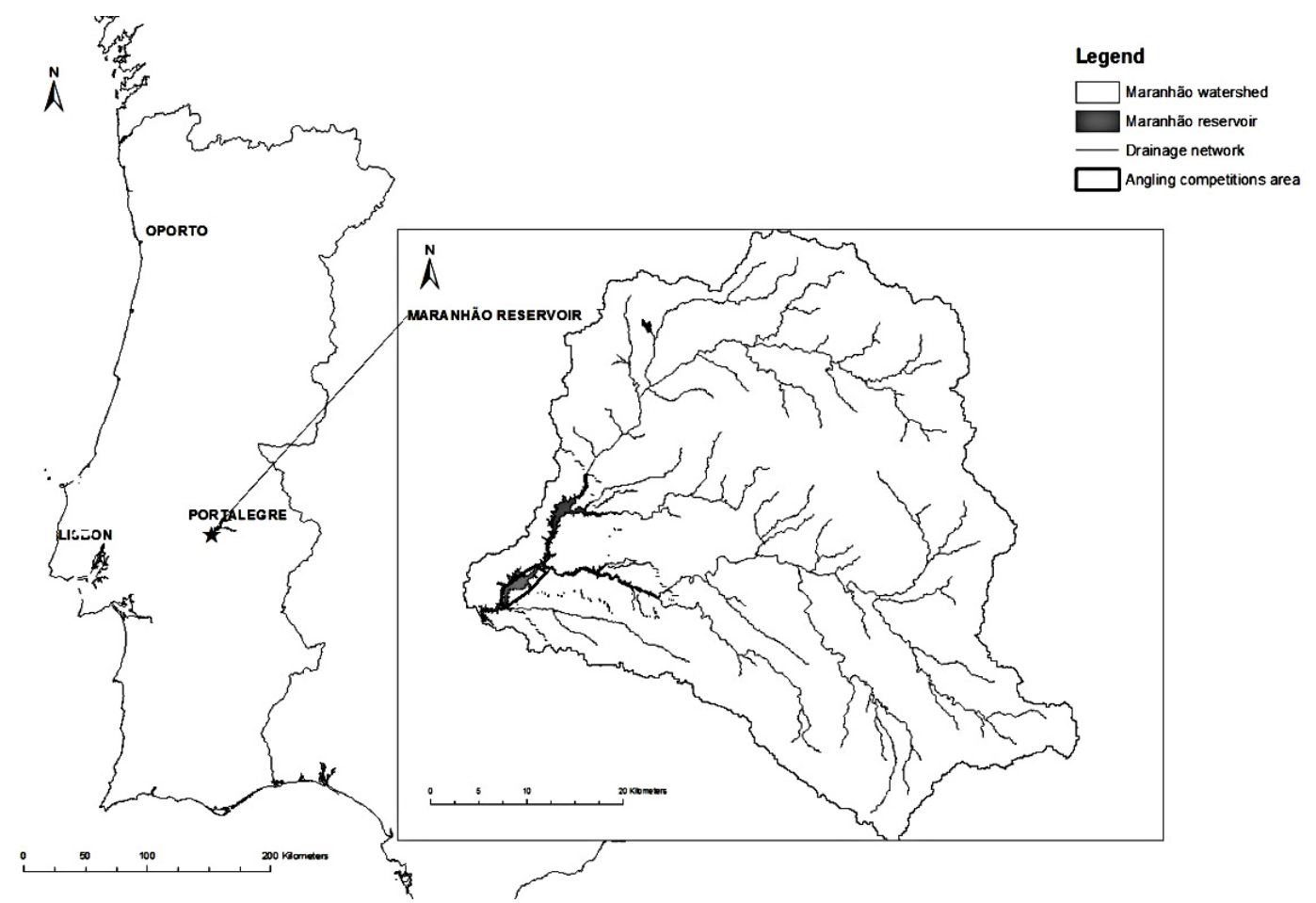

\section{Figure 1}

Location of Maranhão reservoir in southeast Portugal, emphasizing the main area where the angling competitions occurred.

This study aims to evaluate whether the nutrient input from the use of commercial groundbait powders in angling completions in Portuguese reservoirs can be balanced out by sacrificing some or all the fish caught in the competitions. Results for some moderate biomanipulation management scenarios (inputs of nutrients vs. outputs of nutrients) considering the data from angling competitions (number of anglers, commercial groundbait powder used, and fish biomass captured) occurred in Maranhão reservoir are presented. The nutrient budget in the reservoir was determined with: (1) total phosphorus (TP) and total nitrogen (TN) loads entering the waterbody through the use of commercial groundbait powders in competitions (inputs), considering different brands; and (2) TP and TN removal from the reservoir through the sacrifice of fish captured (outputs) evaluating different scenarios of moderate biomanipulation.

\section{MATERIAL AND METHODS}

\section{> STUDY AREA}

Maranhão reservoir is a large waterbody in Avis, near the city of Portalegre, with three main tributaries (Figure 1). It was constructed in 1957 and has a total watershed area of $2282 \mathrm{~km}^{2}$, with a maximum length of $30 \mathrm{~km}$, a surface area of $19.6 \mathrm{~km}^{2}$, an effective storage volume of $181 \times 10^{6} \mathrm{~m}^{3}$, and a mean and maximum depth of $12 \mathrm{~m}$ and $44 \mathrm{~m}$ respectively. The reservoir mean water temperatures vary from $11^{\circ} \mathrm{C}$ in autumn-winter to $26^{\circ} \mathrm{C}$ in spring-summer. Mean values of transparency (Secchi disk), total suspended solids, chlorophyll a and dissolved oxygen (\%), for autumn-winter and spring-summer months, range from 1.8 to $1.4 \mathrm{~m}, 7.5$ to $5.7 \mathrm{mg} \cdot \mathrm{L}^{-1}, 7$ to $12 \mu \mathrm{g} \cdot \mathrm{L}^{-1}$, and 71 to $86 \%$, respectively (values obtained from the national online database of water resources, http://www.snirh.pt). The primary use of this reservoir is to supply irrigation to crops on the valleys downstream. 
Maranhão reservoir is the most popular reservoir in Southern Portugal for angling competitions. In almost three decades of angling data (see Amaral et al., 2013), this reservoir has hosted 65154 anglers in 417 angling competitions, with an average angling effort of nearly 40 anglers per hour of competition. The biomass of coarse fish is abundant as a result of plentiful food sources. Fish fauna is mainly formed by non-native species like common carp, goldfish, and recently for bleak, but also with native species as barbel and nase.

\section{>INPUTS AND OUTPUTS FROM ANGLING COMPETITIONS}

The study comprised determining the quantities of TP (as elemental P) and TN (as elemental $\mathrm{N}$ ) involved in angling competitions, i.e.: (i) the loads into the reservoir resulting from the use of commercial groundbait powders in those events (TP and TN inputs); and (ii) the depletion of biomass related with fish captured and sacrificed (TP and TN outputs).

To determine the brands of commercial groundbait powders most purchased by Portuguese freshwater anglers a telephonic survey questionnaire was applied to 70 fishery shops randomly selected. Typically, the packaging of commercial groundbait does not reveal the composition of the product or the quantities of each component used in the formula, and specially producers do not disclose the values of TP and TN associated with their products.

From the 26 different brands referred in the telephonic survey, 10 of the most purchased were sampled and analysed in order to estimate the most common values of TP and TN present in the powders. Chemical analyses were performed at the Laboratory of Chemical Analysis of the Instituto Superior Técnico, accredited by the Portuguese Institute of Accreditation (IPAC; L0108 trials). To determine the quantity of TP present in each sample, the SMEWW 3120 (Inductively Coupled Plasma [ICP]) method was used (APHA et al., 2005), and to quantify TN in each sample an elemental analysis using the internal method M.M. 8.6 (A.E.) was performed. This method is based on the complete oxidation of the sample converting all organic substances into combustion gases that pass through a reduction furnace (quartz tube furnace at about $1030{ }^{\circ} \mathrm{C}$ ) and are swept into the chromatographic column, where they are separated and detected quantitatively. In the process, excess oxygen is removed by contact with copper, and nitrogen oxides are reduced to elemental nitrogen.

The Portuguese public agency that manages inland fisheries (Institute for the Conservation of Nature and Forest [ICNF]) requires that for each angling competition the organizers complete and submit a statistical record. On those records the number of anglers in competition, the species caught (counting the number and total weight by species), and the duration of the competition are reported. The records from angling competitions performed in Maranhão reservoir from January 2001 to December 2009 were compiled to establish the total anglers per year and the total fish biomass captured by species per year.

Fish species recorded as the most captured in these competitions were sampled and chemically analysed to determine the most common values of TP and TN for each species. The fish species sampled were: common carp, goldfish, barbel, bleak, and pumpkinseed. Since it was not possible to sample Iberian nase, it was considered for the biomass output calculations that nase have the same contents in TP and TN as bleak. Largemouth bass was also not sampled because of its low frequency in catches in these competitions. Sampling was conducted during an angling competition in August 2009 collecting five fish per species. Chemical analyses were performed at the Laboratory of the Research Institute of Fisheries and Marine (IPIMAR). Combined samples mixing the five fish of each fish species were made. To determine the quantity of TP present in each species, the molecular absorption method was used (APHA et al., 2005), and for quantifying the TN for each species the Dumas method (Saint-Denis and Goupy, 2004) was performed.

The TP and TN inputs into the reservoir from the use of groundbait powders in angling competitions and the outputs resulting from the sacrifice of fish captured by anglers were calculated per year. Scenarios for different groundbaiting pressures and for biomass manipulation were studied considering the use of different groundbait brands, quantities of groundbait used per angler, and the release/sacrifice of biomass captured in angling competitions. 


\section{Table I}

Results of chemical analysis performed on the 10 samples of commercial groundbait more purchased by Portuguese freshwater anglers. The elements determined were total phosphorous (TP) and total nitrogen $(T N)$, either in $\mathrm{g} \mathrm{kg}^{-1}$ of groundbait. All brands analyzed are richer in TN than in TP. Groundbait (+) input values were calculated considering the results of Groundbait \# 10 sample powder, and Groundbait (-) input values were calculated from Groundbait \# 1 results.

\begin{tabular}{|l|c|c|}
\hline Groundbait samples & TP & TN \\
\hline Groundbait \# 1 & 1.5 & 12 \\
Groundbait \# 2 & 1.9 & 16 \\
Groundbait \# 3 & 2.1 & 13 \\
Groundbait \# 4 & 2.1 & 12 \\
Groundbait \# 5 & 2.5 & 15 \\
Groundbait \# 6 & 3.5 & 18 \\
Groundbait \# 7 & 3.6 & 18 \\
Groundbait \# 8 & 3.7 & 21 \\
Groundbait \# 9 & 5.3 & 17 \\
Groundbait \# 10 & 6.3 & 31 \\
\hline
\end{tabular}

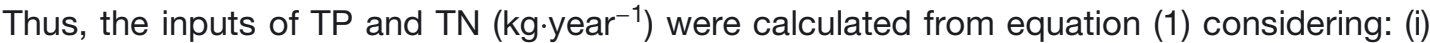
the number of anglers in competitions per year; (ii) the quantity of commercial groundbait powders used by anglers; and (iii) the values of TP and TN from groundbait, obtained from the chemical analysis $\left(\mathrm{TP}_{\text {grdbait }}\right.$ and $\left.\mathrm{TN}_{\text {grdbait }} ; \mathrm{g} \cdot \mathrm{kg}^{-1}\right)$. For the quantity of groundbait used by anglers, three different pressures were established for the calculations: (1) use of $5 \mathrm{~kg}$ of groundbait per angler in competition, (2) use of $3 \mathrm{~kg}$ of groundbait per angler, and (3) the use of $1.5 \mathrm{~kg}$ of groundbait per angler. Regarding the contents in $\mathrm{TP}_{\text {grdbait }}$ and $\mathrm{TN}_{\text {grdbait }}$, for each biomanipulation scenario the use of groundbait powders with: a) the highest values present in the analysed groundbait samples for calculations of Groundbait (+) (TP $=6.3 \mathrm{~g} \cdot \mathrm{kg}^{-1}$ and TN $=$ $31 \mathrm{~g} \cdot \mathrm{kg}^{-1}$; values from Table I); and b) the lowest values for calculations of Groundbait (-) (TP $=1.5 \mathrm{~g} \cdot \mathrm{kg}^{-1}$ and $\mathrm{TN}=12 \mathrm{~g} \cdot \mathrm{kg}^{-1}$; values from Table I) was also considered.

$$
\text { Groundbait }_{\text {Inputs }}\left(\mathrm{TP} \mathrm{g} \text { or TN g) }=\text { anglers } \times \operatorname{grdbait}(\mathrm{kg}) \times \operatorname{TP}_{\text {grdbait }} \text { or } \mathrm{TN}_{\text {grdbait }}\left(\mathrm{g} \cdot \mathrm{kg}^{-1}\right)\right. \text {. }
$$

The outputs of TP and TN $\left(\mathrm{kg} \cdot \mathrm{year}^{-1}\right)$ from biomass manipulation were calculated from equation (2) taking into account the quantities of fish captured and sacrificed for each species per year (Fish; $\mathrm{kg}$ ) and the values of TP and TN obtained from the chemical analysis performed for each species $\left(\mathrm{TP}_{\mathrm{sp}}\right.$ and $\left.\mathrm{TN}_{\mathrm{sp}} ; \mathrm{g} \cdot \mathrm{kg}^{-1}\right)$. The quantities of fish captured and sacrificed were determined considering the scenarios: (B0) release of all biomass; (B1) release of barbels, nases, and carps larger than $35 \mathrm{~cm}$ (i.e. to enhance population of carp's trophy dimension in the reservoir); (B2) release of barbels and nases; and (B3) sacrifice of all biomass captured.

$$
\text { Biomassoutputs }\left(\mathrm{TP} g \text { or TN g) }=\sum_{i=1}^{n} \text { Fish }(\mathrm{kg}) \times \operatorname{TP}_{\mathrm{sp}}\left(\mathrm{g} \cdot \mathrm{kg}^{-1}\right) \text { or } \mathrm{TN}_{\mathrm{sp}}\left(\mathrm{g} \cdot \mathrm{kg}^{-1}\right)\right. \text {. }
$$

The final balance between inputs and outputs of TP and TN was executed from equation (3) pondering the mean annual values of inputs from groundbaiting and the outputs from biomass sacrificed in angling competitions.

$$
\text { TP or } \mathrm{TN}_{\text {Balance }}(\mathrm{kg})=\overline{\text { Groundbait }_{\text {inputs }}}-\overline{\text { Biomass }_{\text {outputs }}} \text {. }
$$

\section{RESULTS}

The chemical analyses performed on the 10 samples of commercial groundbait most purchased by anglers revealed that groundbait powders may have very different contents in 


\section{Table II}

Summary data from angling competitions performed in Maranhão reservoir, from January 2001 to December 2009, including the number of angling competitions performed in the year (competitions), the total angling effort (AE; angler. $\mathrm{h}^{-1}$ ), the total biomass captured (Biomass; $\mathrm{kg}$ ), the biomass captured per

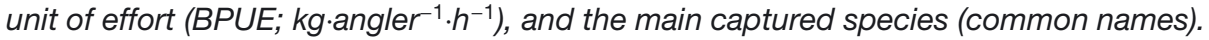

\begin{tabular}{|c|c|c|c|c|c|}
\hline Year & Competitions & AE & Biomass & BPUE & Species captured \\
\hline $\mathbf{2 0 0 1}$ & 7 & 44.51 & 1952 & 0.056 & Carp; Barbel; Largemouth bass Pumpkinseed \\
\hline $\mathbf{2 0 0 2}$ & 9 & 32.37 & 5799 & 0.097 & Carp; Barbel; Goldfish; Nase; Pumpkinseed \\
\hline $\mathbf{2 0 0 3}$ & 5 & 45.79 & 2230 & 0.135 & $\begin{array}{c}\text { Carp; Barbel; Nase; Pumpkinseed; } \\
\text { Largemouth bass }\end{array}$ \\
\hline $\mathbf{2 0 0 4}$ & 6 & 28.83 & 3056 & 0.126 & Carp; Goldfish; Barbel; Nase \\
\hline $\mathbf{2 0 0 5}$ & 13 & 28.71 & 5016 & 0.069 & $\begin{array}{c}\text { Carp; Barbel; Nase; Pumpkinseed; } \\
\text { Goldfish; Largemouth bass }\end{array}$ \\
\hline $\mathbf{2 0 0 6}$ & 24 & 21.34 & 8467 & 0.046 & $\begin{array}{c}\text { Carp; Goldfish; Barbel; Nase; Pumpkinseed; } \\
\text { Largemouth bass }\end{array}$ \\
\hline $\mathbf{2 0 0 7}$ & 24 & 19.57 & 11897 & 0.063 & $\begin{array}{c}\text { Carp; Goldfish; Barbel; Nase; } \\
\text { Largemouth bass; Pumpkinseed; Bleak }\end{array}$ \\
\hline $\mathbf{2 0 0 8}$ & 29 & 21.06 & 9957 & 0.040 & $\begin{array}{c}\text { Carp; Bleak; Goldfish; Barbel; } \\
\text { Pumpkinseed; Largemouth bass }\end{array}$ \\
\hline $\mathbf{2 0 0 9}$ & 14 & 21.93 & 5596 & 0.084 & $\begin{array}{r}\text { Carp; Bleak; Goldfish; Barbel; Pumpkinseed; } \\
\text { Largemouth bass }\end{array}$ \\
\hline
\end{tabular}

terms of TN and TP (Table I). In the samples analysed, some were richer in TP and TN with the content of TN varying from 12 to $31 \mathrm{~g} \cdot \mathrm{kg}^{-1}$ and the content of TP from 1.5 to $6.3 \mathrm{~g} \cdot \mathrm{kg}^{-1}$. The highest and the lowest values of TP and TN were applied in the calculations of groundbaiting inputs and in balances presented forward.

Data from angling competitions performed in Maranhão reservoir from January 2001 to December 2009 are summarized in Table II. The year with more angling competition records was 2008 with 29 competitions, although it was a year with a lower angling effort, only 21.06 angler $\cdot \mathrm{h}^{-1}$. By contrast, in 2003 fewer competitions were performed, however more anglers gathered in those events registering higher angling effort (45.79 angler $\cdot \mathrm{h}^{-1}$ only in five competitions) and higher quantity of biomass captured per unit of effort (BPUE; $0.135 \mathrm{~kg} \cdot$ angler $\left.^{-1} \cdot \mathrm{h}^{-1}\right)$. Competitions in 2006, 2007, and 2008 presented the highest values of biomass captured, ranging from 8 to 12 tonnes. However, in 2006 and 2008 values of biomass captured per unit of effort were the lowest $(0.046$ and 0.040 , respectively). The main species captured were common carp, goldfish, barbel, Iberian nase, pumpkinseed, largemouth bass, and bleak (with registers since 2007). Analysing the total biomass captured (\%) per species (Figure 2), most of the biomass captured was of carp (84.3\%) followed by goldfish $(6.4 \%)$, barbel (4.2\%), and bleak (3.4\%); values of biomass captured of pumpkinseed $(0.8 \%)$, nase $(0.6 \%)$, and largemouth bass $(0.2 \%)$ were less representative.

Results from chemical analyses performed on the main fish species captured by anglers in competitions revealed that species sampled have relatively similar contents of TP $\left(\mathrm{g}^{\mathrm{kg}} \mathrm{kg}^{-1}\right)$ and TN $\left(\mathrm{g} \cdot \mathrm{kg}^{-1}\right)$ (Table III). Content in TP varied from 2.0 to $2.9 \mathrm{~g} \cdot \mathrm{kg}^{-1}$, and TN varied from 26 to $30 \mathrm{~g} \cdot \mathrm{kg}^{-1}$. Goldfish was the species with lower contents of TP and TN whereas the bleak had the highest values of these nutrients.

According to the balance of inputs and outputs of TP and TN from angling competitions for the biomanipulation scenarios studied, it was possible to determine that the inputs from the use of commercial groundbait powders could be compensated by sacrificing fish captured (Figure 3). Results from the scenarios considering the removal of biomass captured and the use of Groundbait (-) in the competitions performed showed that even using $5 \mathrm{~kg}$ of groundbait per angler the balance of TP (graphic A.1) and TN (graphic B.1) is negative, meaning that the outputs from the sacrifice of part (scenarios B1 and B2) or all of the fish captured (scenario B3) were higher than the inputs from groundbaiting. For Groundbait (+), the inputs 


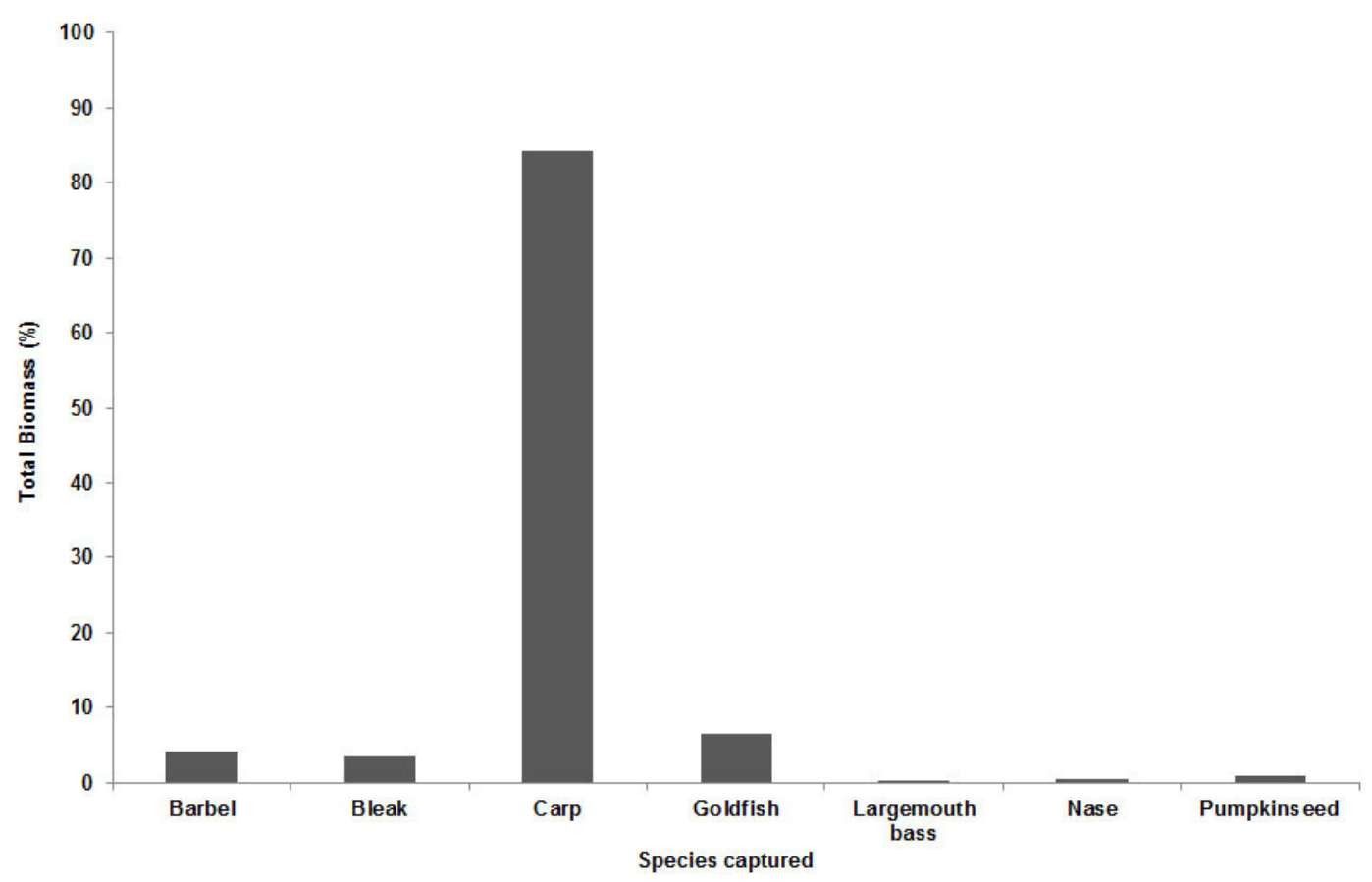

Figure 2

Total biomass (\%) of the main species captured in the angling competitions of Maranhão reservoir, from January 2001 to December 2009. Most of the biomass captured was carp (84.3\%), followed by goldfish $(6.4 \%)$, barbel $(4.2 \%)$, and bleak (3.4\%, with the first registers of capture of this species dating from 2007. Bleak is currently the most abundant specie on catches). Pumpkinseed, nase, and largemouth bass represented only $0.8 \%, 0.6 \%$, and $0.2 \%$ of the captures, respectively.

\section{Table III}

Results from chemical analyses performed on the main fish species captured by anglers in the competitions carried out in Maranhão reservoir. The elements determined were total phosphorous (TP) and total nitrogen (TN), in $\mathrm{g} \cdot \mathrm{kg}^{-1}$ of fish.

\begin{tabular}{|l|c|c|}
\hline Species & TP & TN \\
\hline Barbel & 2.2 & 30 \\
Bleak & 2.9 & 30 \\
Carp & 2.2 & 27 \\
Goldfish & 2.0 & 26 \\
Nase $^{(*)}$ & $2.9^{(*)}$ & $30^{(*)}$ \\
Pumpkinseed & 2.4 & 26 \\
\hline
\end{tabular}

*Note: It was not possible to determine the values of TP and TN for nase, so the values defined for bleak were used in calculations. Largemouth bass was not sampled due to his low representation in the catches.

of TP equated the outputs only when it was used $1.5 \mathrm{~kg}$ of groundbait per angler and all the biomass captured was sacrificed (graphic A.3, scenario B3). However, in TN balance the inputs from groundbaiting equated the outputs in graphic B.2 considering the use of $3 \mathrm{~kg}$ of groundbait per angler and the sacrifice of part of the biomass captured releasing the barbels, the nases, and the carps larger than $35 \mathrm{~cm}$ (scenario B1). Evaluating the results from the use of Groundbait (+) and Groundbait (-) in scenario B0, which set the release of all biomass captured so there were no exits of TP and TN from the reservoir, it is noted that inputs of TP from Groundbait (+) were approximately four times higher than the inputs from the use of Groundbait (-), and for TN the inputs from Groundbait (+) were nearly three times higher than the inputs from Groundbait (-). 

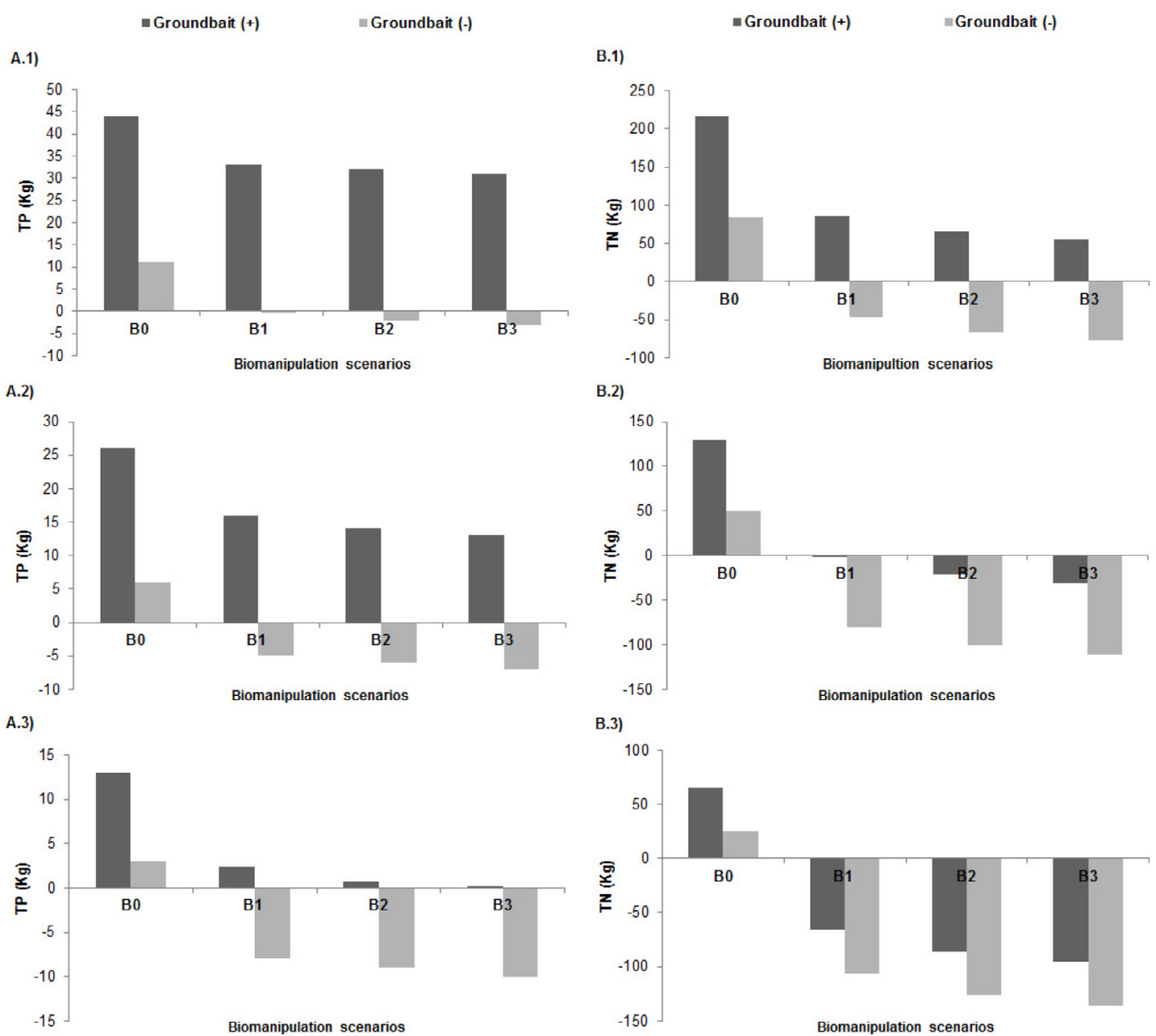

Figure 3

Results of biomanipulation scenarios studied considering the differences of inputs and outputs of TP (A) and TN (B) from angling competitions. Calculations of inputs from groundbaiting were made stipulating the use of: (1) $5 \mathrm{~kg}$ of groundbait per angler; (2) $3 \mathrm{~kg}$ of groundbait per angler; and (3) $1.5 \mathrm{~kg}$ of groundbait per angler. Two groundbait brands were selected having different eutrophication potential: Groundbait (+) favoring higher eutrophication and Groundbait (-) favoring less eutrophication. For the output values, the studied scenarios from biomass manipulation were: (B0) release of all biomass;( B1) release of barbels, nases, and big carps $>35 \mathrm{~cm}$; (B2) release of natives, barbels and nases; and (B3) sacrifice of all biomass captured. Graphically, the positive values correspond to loads of TP and TN into the reservoir; the negative values correspond to removal of TP and TN from the reservoir.

\section{DISCUSSION}

Voluntary catch-and-release angling has been seen by anglers as a conservation ethics and an ecological attitude (Arlinghaus et al., 2007). However, catch-and-release angling may induce to overcrowding of fish in reservoirs leading to competition for space and foodresources (Arlinghaus, 2007) and triggering the fish populations to a small growth. Furthermore, with catch-and-release angling in competitions performed in reservoirs the removal of nutrients (especially TP and TN) from the waterbody through the sacrifice of fish captured does not occur, therefore the balance out of nutrients from groundbaiting is not permitted.

Our study highlights that through an effective angling management in reservoirs it is possible to implement a moderate biomanipulation of the fish populations, that are normally quite numerous but in most cases poorly structured (Ferreira and Godinho, 2002). Likewise, by implementing an effective management of fish captured in angling competitions the control of exotic fish fauna could be promoted and the nutrients inputs from groundbaiting may be balanced, decreasing the reservoir eutrophication. 
Furthermore, the removal of biomass through sacrifice of the fish captured, totally or selecting some fish species and/or dimensions (e.g. removal of carps smaller than $35 \mathrm{~cm}$, as proposed in this study, in order to promote more resources for "trophy carps"), may stimulate more matured and well-adjusted aquatic communities, enriching the angling experiences through the quality of catches (Cowx et al., 2010; Isermann and Paukert, 2010; Arlinghaus et al., 2013). At the same time, through that removed biomass, the load of nutrients in the reservoir from the groundbait powders used in angling competitions could be balanced out, and in some cases the outputs of TP and TN from the reservoir may exceed the inputs of those nutrients from groundbaiting according to the types of groundbaits selected by anglers.

Considering the data from angling competitions performed in Maranhão reservoir and the chemical analyses performed in fish and in commercial groundbait powders selected, by instructing anglers to sacrifice only the biomass captured of the exotic species bleak (reported by Almeida et al., 2014 as responsible for trophic competition and hybridization with endemic Iberian fish fauna), goldfish, and carp smaller than $35 \mathrm{~cm}$, and using a groundbait powder with low eutrophication potential, the inputs of TP and TN from groundbaiting may be compensated. However, when using a groundbait powder richer in TP and TN, with a higher eutrophication potential, it may be needed to sacrifice all fish captured in order to balance those nutrients inputs and anglers should use fewer quantities of those powders.

Some environmental nongovernmental organizations have attempted to ban the use of groundbait in angling invoking that it contributes to eutrophication of reservoirs. As a containment measure, and to limit groundbaiting, Portuguese water managers have implemented the obligation of an authorization to groundbait in angling competitions and the Portuguese Angling Federation also decreased the quantities of groundbait that can be used in their competitions.

Most of all, anglers should be informed of the water quality problems that may arise from the practice of catch-and-release angling and groundbaiting. Anglers must be advised to be more selective in the release of fish captured back to the reservoir and to use smaller quantities of groundbaits as well as choose commercial groundbaits with low eutrophication potential. For that, trademarks of groundbaits should provide more information about the eutrophication potential of their products in order to allow anglers to choose in a more conscious and environmentally friendly manner. Furthermore, that information could be integrated into a more holistic approach to reservoir management. Moreover, as a result of the increasing importance of angling, the pressures resulting from it should be more carefully considered and further studies should be made attending to a more holistic approach of angler-ecosystem relationship.

\section{ACKNOWLEDGEMENTS}

We would like to acknowledge the technicians of Inland Fisheries Division from National Forest Authority (currently in ICNF) for all the information on freshwater recreational fisheries kindly provided; and the $1 .^{a}$ Associação Regional de Pesca Desportiva de Rio (ARPDR), and Rui Silva Marques for the technical assistance. Thanks are also extended to Ms. Jennifer de Jesus for her English-as-second-language editing services. Susana Amaral was supported by a grant from Instituto Superior de Agronomia and Universidade Técnica de Lisboa (currently Universidade de Lisboa).

\section{REFERENCES}

Alexandre C.M., Ferreira T.F. and Almeida P.R., 2013. Fish assemblages in non-regulated and regulated rivers from permanente and temporary Iberian systems. River Res. Appl., 29, 1042-1058. 3 4 5 6 7 8 9 10 11 
Amaral S.D., Brito D., Ferreira M.T., Neves R. and Franco A., 2013. Modeling water quality in reservoirs used for angling competition: can groundbait contribute to eutrophication? Lake Reserv. Manage., 29, 257-269.

American Public Health Association (APHA), American Water Works Association (AWWA), Water Environment Federation (WEF), 2005. SMEWW - Standard methods for the examination of water and wastewater, 21st ed., In: Eaton A., Clesceri L.S., Rice E.W., Greenberg A.E. (eds.). Washington DC, USA.

Arlinghaus R., 2007. Voluntary catch-and-release can generate conflict within the recreational angling community: a qualitative case study of specialised carp, Cyprinus carpio, angling in Germany. Fisheries Manag. Ecol., 14, 161-171.

Arlinghaus R. and Niesar M., 2005. Nutrient digestibility of angling baits for carp, Cyprinus carpio, with implications for groundbait formulation and eutrophication control. Fisheries Manag. Ecol., 12, 91-97.

Arlinghaus R., Cooke S.J., Lyman J., Policansky D., Schwab A., Suski C., Sutton S.G. and Thorstad E.B., 2007. Understanding the Complexity of Catch-and-Release in Recreational Fishing: An Integrative Synthesis of Global Knowledge from Historical, Ethical, Social, and Biological Perspectives. Rev. Fish. Sci., 15, 75-167.

Arlinghaus R., Cooke S.J. and Potts W., 2013. Towards resilient recreational fisheries on a global scale through improved understanding of fish and fisher behaviour. Fisheries Manag. Ecol., 20, 91-98.

Banha F., Ilhéu M.and Anastácio P.M., 2015. Angling web forums as an additional tool for detection of new fish introductions: the first record of Perca fluviatilis in continental Portugal. Knowl. Manag. Aquat. Ecosyst., 416, 03.

Carpenter S.R. and Lathrop R.C., 2008. Probabilistic estimate of a threshold for eutrophication. Ecosystems, 11, 601-613.

Chumchal M.M., Nowlin W.H. and Drenner R.W., 2005. Biomass-dependent effects of common carp on water quality in shallow ponds. Hydrobiologia, 545, 271-277.

Clavero M. and Hermoso V., 2011. Reservoirs promote the taxonomic homogenization of fish communities within river basins. Biodivers. Conserv., 20, 41-57.

Clavero M., Hermoso V., Aparicio E. and Godinho F.N., 2013. Biodiversity in heavily modified waterbodies: native and introduced fish in Iberian reservoirs. Freshwater Biol., 58, 1190-1201.

Cowx I.G. and Gerdeaux D., 2004. The effects of fisheries management practises on freshwater ecosystems. Fisheries Manag. Ecol., 11, 145-151.

Cowx I.G., Arlinghaus R. and Cooke S.J., 2010. Harmonizing recreational fisheries and conservation objectives for aquatic biodiversity in inland waters. J. Fish Biol., 76, 2194-2215.

Drenner R. and Hambright, K., 1999. Biomanipulation of fish assemblages as a lake restoration technique. Arch. Hydrobiol., 146, 129-165.

Ferreira M.T. and Godinho F., 2002. Comunidades biológicas de albufeiras. In: Moreira I., Ferreira M.T., Cortes R., Pinto P. and Almeida P.R. (eds.), Ecossistemas Aquáticos e Ribeirinhos - Ecologia, Gestão e Conservação, Instituto da Água, Lisboa, 10.3-10.25.

Fischer J.R., Krogman R.M. and Quist M.C., 2013. Influences of native and non-native benthivorous fishes on aquatic ecosystem degradation. Hydrobiologia, 711, 187-199.

Granado-Lorencio C., 2002. Ecologia de Pesces, Universidad de Sevilla, Secretariado de Publicaciones, Sevilha, $353 \mathrm{p}$.

Hansson L., Annadotter H., Bergman E., Hamrin S., Jeppesen E., Kairesalo T., Luokkanem E., Nilsson P., Søndergaard M. and Strand J., 1998. Biomanipulation as an application of food-chain theory: constraints, synthesis and recommendations for temperate lakes. Ecosystems, 1, 558-574.

Isermann D.A. and Paukert C.P., 2010. Regulating harvest. In: Hubert W.A. and Quist M.C. (eds.), Inland Fisheries Management in North America $3^{\text {rd }}$ edn., Bethesda, MD: American Fisheries Society, 185-212.

Kasprzak P., Benndorf J., Mehner T. and Koschel R., 2002. Biomanipulation of lake ecosystems: an introduction. Freshwater Biol., 47, 2277-2281.

Lewin W.C., Arlinghaus R. and Mehner T., 2006. Documented and potential biological impacts of recreational fishing: Insights for management and conservation. Rev. Fish. Sci., 14, 305-367.

Mehner T., Benndorf J., Kasprzak P. and Koschel R., 2002. Biomanipulation of lake ecosystems: successful applications and expanding complexity in the underlying science. Freshwater Biol., 47, 2453-2465. 
Mehner T., Arlinghaus R., Berg S., Dörner H., Jacobsen L., Kasprzak P., Koschel R., Schulze T., Skov C., Wolter C. and Wysujack K., 2004. How to link biomanipulation and sustainable fisheries management: a step-by-step guideline for lakes of the European temperate zone. Fisheries Manag. Ecol., $11,261-275$.

Nieoczym M. and Kloskowski J., 2013. The role of body size in the impact of common carp Cyprinus carpio on water quality, zooplankton, and macrobenthos in ponds. Int. Rev. Hydrobiol., 98, 1-10.

Niesar M., Arlinghaus R., Rennert B. and Mehner T., 2004. Coupling insights from a carp, Cyprinus carpio, angler survey with feeding experiments to evaluate composition, quality and phosphorus input of groundbait in coarse fishing. Fisheries Manag. Ecol., 11, 225-235.

Saint-Denis T. and Goupy J., 2004. Optimization of a nitrogen analyser based on the Dumas method. Anal. Chim. Acta, 515, 191-198.

Santos J.M., Ferreira M.T., Pinheiro A.N. and Bochechas J., 2006. Effects of small hydropower plants on fish assemblages in medium-sized streams in Central and Northern Portugal. Aquat. Conserv., 16, 373-388.

Smith V.H., Tilman G.D. and Nekola J.C., 1999. Eutrophication: impacts of excess nutrient inputs on freshwater, marine, and terrestrial ecosystems. Environ. Pollut., 100, 179-196.

Vanni M.J., 2002. Nutrient cycling by animals in freshwater ecosystems. Annu. Rev. Ecol. Evol. S., 33, 341-370.

Weber M.J. and Brown M.L., 2009. Effects of Common Carp on Aquatic Ecosystems 80 Years after "Carp as a Dominant": Ecological Insights for Fisheries Management. Rev. Fish. Sci., 17, 524-537.

Wiley R.W. and Wydoski R.S., 1993. Management of undesirable fish species. In: Kohler C.C. and Hubert W.A. (eds.), Inland Fisheries Management in North America, American Fisheries Society, Bethesda, MD, 335-354.

Wolos A., Teodorowicz M. and Grabowska K., 1992. Effect of groundbaiting on anglers' catches and nutrient budget of water bodies as exemplified by Polish lakes. Aquacult. Fish. Manage., 23, 499-509.

Cite this article as: S.D. Amaral, A. Franco and M.T. Ferreira, 2015. Moderate biomanipulation for eutrophication control in reservoirs using fish captured in angling competitions. Knowl. Manag. Aquat. Ecosyst., 416, 14. 